\title{
Syndicate Size In Global IPO Underwriting
}

Demissew Diro Ejara, (E-mail: dejara@newhaven.edu), University of New Haven

\begin{abstract}
This study analyzes factors that determine syndicate size in ADR IPO underwriting. The information gathering role of investment bankers, complexity and risk of issue, corporate governance and transparency environment factors, and potential business relations are the basis for the analyses. Empirical results indicate decreasing syndicate size over time. No significant relation is found between syndicate size and initial day return of IPOs. The transparency environment, dilution effect of the issue, growth stage of the issuer, lead underwriter reputation, offering size and ownership concentration are found to have significant effects on syndicate size.
\end{abstract}

\section{INTRODUCTION}

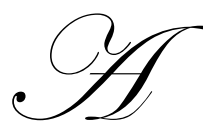

company that desires to issue securities to raise capital has two options: self-underwrite its security or enter into a contract with investment banker(s) to underwrite the security. If it chose to engage an underwriter, there are two types of contracts: best efforts and firm commitment contracts. Under best efforts contract, the firm assumes the risk of distribution. The investment banker makes its best effort to sell the issue and the company gets its capital net of underwriter compensation piecemeal as each share is sold. The investment bankers' responsibilities are managing the issue and selling. Under firm commitment contracts, the underwriters buy the securities from the issuing firm and sell them to the public. The firm gets its capital (net of underwriters' compensation) immediately and the risk of distribution is shouldered by the investment bankers. The investment bankers underwrite, manage and sell the issue.

In either case, the issuing company selects an investment banker and enters into an underwriting contract. The investment banker that won the contract invites other investment bankers and forms a syndicate. Why would it invite others and share its business? Probable reasons are (1) it needs to share the capital commitment necessary to underwrite the security issue, (2) it needs to share the marketing effort to sell the shares, (3) it needs to share expertise and skills in securities underwriting to price the shares more accurately, (4) it needs to establish business relations since those invited to the syndicate would likely invite it when they win future underwriting contracts, and (5) sometimes the issuing firm desires inclusion of some investment banks in the syndicate. These imply that size of the issue, riskiness of the issue, the size and reputation of the investment banker, the desire of partnership relations and complexity of the issue determine the size and composition of an underwriting syndicate. This paper tests these variables for ADR IPO issues.

Syndication is a major financial intermediation role played by investment bankers and in the case of loan syndication, by commercial banks, insurance companies and other financial institutions. This project will examine the syndication of underwriting securities. More specifically, it examines the underwriting of American Depositary Receipts (ADR) Initial Public Offering (IPO). ADRs are foreign company negotiable instruments that trade on US stock exchanges. Since they represent foreign companies that are large in size and usually of global reputation, their syndication presents an opportunity to examine the issue of syndicate formation and syndicate size on a global scale. The selection of IPO underwriting helps examine the issue of underwriting risk that syndicate members face.

Investment bankers perform three main functions in the issuance of stocks: (1) Leading or managing the syndication, which is an organizing role, (2) underwriting, which requires capital commitment and (3) selling or distributing the securities to the public. One or more investment bankers are managers (or lead underwriters). The rest of the syndicate members may engage in underwriting and/or selling. The fee for the investment bankers is called gross spread and averages 7\% of the issue size (Chen and Ritter (2000)). The gross spread is divided into the three functions described above: management fee, underwriting fee and selling concessions and each constitutes 20\%, 20\% 
and $60 \%$ on average (Torstila (2001)). Each member of the syndicate gets from these fees depending on its participation and its contribution. If an investment bank wins the contract from an issuing company, manages, underwrites and sells the securities alone, it can keep the entire fee. So why would an investment banker invite others to the syndicate and share its business and its revenue?

The paper is organized as follows. The following section presents some theoretical framework and formulates hypothesis. Section 3 describes the data. Section 4 presents analysis and results and section 5 concludes.

\section{THEORETICAL FRAMEWORK}

\section{Information Generation Hypothesis}

Corwin and Schultz (2005) examine the information generating role of syndicates and indicate that the larger the syndicate size, the better the information gathering and the more accurate the pricing of the securities. So, one reason for inviting more underwriters to a syndicate is to help reduce information asymmetry and price securities more accurately. This implies, in the case of IPOs, that issues with large syndicate would be less underpriced than issues with few underwriters. More accurate pricing of IPO shares helps to reduce the risk investment bankers face to their reputation from the issuing companies if securities are underpriced and the class action law suits they face from investors if the securities are overpriced and investors lose subsequent to the issue. Ejara and Ghosh (2004) report that on the average, the syndicate size for ADR IPOs is larger than for US IPOs and ADR IPOs are less underpriced than US IPOs. This is consistent with Corwin and Schultz (2005) since ADR IPOs are foreign companies and more information gathering is necessary.

\section{Skill Sharing Or Acquisition}

Underwriters need skills in underwriting. If the issue is of special nature in terms of industry, region, type of issue, complexity, etc. special skills may be needed. It is likely that the lead underwriter includes in the syndicate Asian underwriters for ADR IPOs from Asia and European underwriters for ADR issues from Europe. Such invitations can sometimes be due to the desire to establish future business relations. An invited investment banker is likely to invite when it wins business. According to Smith and Walter (2003) in international loan syndication, an investment bank's visibility could be enhanced for being in a syndicate together with a bank with high reputation. This implies that low reputation underwriters desire to be in a syndicate with high reputation underwriters.

\section{Risk Sharing}

Underwriters face different types of risk. One is the risk of failure of the issue. In firm commitment contracts, investment banks face the risk of distribution of the shares in the issue. If the issue fails, their capital would be tied up for long period and they may actually lose. Increasing syndicate size reduces such risk through better information gathering, marketing skills, sharing effort and also reducing the size of exposure to each underwriter. This becomes even more important if the issue size is large and if the investment banker is not large (see Foster (1989)). Second, if the issuing firm underperforms subsequent to issue and shareholders lose on their investment, the underwriters face class action law suit which damages their reputations. Increasing syndicate size helps reduce this risk indirectly through better information gathering and underwriting skill contribution. Better information gathering helps the underwriter perform its due diligence investigation better and comply with the legal disclosure requirements.

\section{Issuer's Desire}

Corporate issuers sometimes want to include their favorite investment banker in the syndicate. This could be because of existing or potential future business relations. Sometimes, a corporate issuer may limit the size of the syndicate by questioning the merits of including each underwriter in the syndicate. Tunick (2004) and Wirth (1997) describe the recent declining trend in the size of underwriting syndicate as resulting from issuing firms' increasing bargaining power in the securities markets, underwriters endowment with large capital and the availability of different risk management techniques in today's financial markets. 


\section{Corporate Transparency Environment}

As stated above, one key role of investment banks is information production. Information generation is difficult if the corporate governance environment is poor and allows for little disclosure. There are two aspects of transparency environment: the internal corporate governance structure and the outside country corporate governance practices. Tight corporate control, where the CEO is entrenched, and concentrated ownership of shares allow for greater private benefits of control (Benos and Weisbach (2004). According to Dyck and Zingales (2002), such private benefits of control in the form of expropriation of corporate wealth through different means are inversely related to the quality of the country's corporate governance environment and disclosure requirements. Private benefits from control are greater in countries rife with corruption, unstable political environment, poor accountability and poor enforcement of the rule of the law. So the internal corporate governance structure and the external transparency environment reinforce each other. Large syndicate is needed for an issue by a firm with concentrated ownership and/or tight control of company by few executives and poor transparency environment.

Table 1: Variable Definition And Hypothesized Relations

The following variables are expected to affect syndicate size and their hypothesized effects are indicated by + and - signs.

\begin{tabular}{|c|c|c|}
\hline $\begin{array}{l}\text { Variable } \\
\text { Name }\end{array}$ & Description & Expected Sign \\
\hline NEW & $\begin{array}{l}\text { Dummy variable with a value of } 1 \text { for IPOs issued during } 1997 \text { or after and } 0 \text { for IPOs issued } \\
\text { before } 1997\end{array}$ & - \\
\hline DEV & Dummy variable with a value of 1 if the IPO is from Developed country and 0 otherwise & - \\
\hline HITECH & Dummy variable with a value of 1 if the IPO firm is a hi-tech company and 0 otherwise & - \\
\hline TRANSP & Index of country transparency (World Bank rating) & - \\
\hline HHB & HH Index of ownership concentration before IPO issue & + \\
\hline DILUTION & Ratio of primary shares offered in the IPO to shares outstanding before IPO & - \\
\hline PARTICI & Ratio of secondary shares offered in the IPO to shares outstanding before IPO & + \\
\hline OFFERV & Value of total shares offered at IPO offer price (shares offered x offer price per share) & + \\
\hline LVALUE & $\log$ of offer value & + \\
\hline TA & Total assets in millions of dollars before IPO & + \\
\hline LTA & log of total assets & + \\
\hline REVG1 & Revenue growth rate during the year before IPO & - \\
\hline PROCEEDS & dummy variable with a value of 1 if the firm gets proceeds from the issue, and 0 otherwise & - \\
\hline IR & initial day return (underpricing of the IPO) & - \\
\hline AGE & age of the firm in years at IPO & - \\
\hline SNPRE1 & S\&P500 index return the first day of IPO & + \\
\hline URANK & lead underwriter rank based on Carter-Manaster system & - \\
\hline PPADJU & partial price adjustment $(\%)$ & + \\
\hline PVADJU & volume adjustment $(\%)$ & + \\
\hline REGIWAIT & waiting period in registration (days) & - \\
\hline RISK & standard dev. Of daily returns for 60-days after IPO & + \\
\hline SNPQ & S\&P500 index return one quarter before IPO date & + \\
\hline INSIDER & Percent of shares owned by insiders before IPO & + \\
\hline PRVT & dummy with a value of 1 for privatization and 0 otherwise & + \\
\hline
\end{tabular}

\section{Summary}

Based on the above discussions, I hypothesize that underwriter syndicate is positively related to the riskiness of the issuer, the size of the issue, complexity of the issue, ownership concentration, and performance of the stock market. Syndicate size is expected to have negative sign with age of the issuing firm, underwriter rank, transparency environment, degree of dilution of ownership in the offering, and the time trend. Table 1 above presents details of the explanatory variables and expected relationship with syndicate size. 


\section{DATA}

The list of ADR IPOs is obtained from Bank of New York and Citibank ADR Departments. This list is verified against IPO lists in Investment Dealers' Digest. Further verification is made by referring to the prospectuses of each IPO. The prospectuses state if there were any trading in the underlying shares before ADR issue. If there is any, that issue is not an IPO and does not enter the sample. After such verifications, 188 ADR IPO sample is established. 55 (29\%) of them are from emerging market countries and the remaining 133 (71\%) are from developed countries. 21 cases are privatizations of previously government owned enterprises.

Company specific data items such as corporate governance variables, offer price, number of shares offered, ownership distribution before issue, total assets, revenues, number of shares issued by original owners, number of new shares issued by the company, age of the company, etc. are hand collected from the prospectuses. HerfindahlHirschman (HH) Index for ownership concentration is calculated by grouping pre-IPO ownership into CEO and affiliates, other insiders, outside corporate, government, Institutions, investment banks if they are part of the underwriting syndicate, venture capitalists and others. S\&P500 index values are obtained from the Center for Research in Security Prices (CRSP) tape. Post-IPO stock prices are also obtained from CRSP and daily return volatilities are calculated based on the first 60-days of trading. Underwriter rank is the Carter and Manaster (1990) reputation ranking and is obtained from Ritter (2001).

Country corporate governance transparency index is obtained from the World Bank study by Kaufmann, Kraay and Mastruzzi (2003). This study establishes index values ranging from -2.5 (worst governance environment) to 2.5 (best governance environment) for all countries for 1996-2002. The index used in this study is average over the years for each country.

\section{ANALYSES AND RESULTS}

Table 2 presents description of the data and preliminary mean comparisons of syndicate size with respect to some variables. The average syndicate size for the IPOs in the sample is 17.63 (median is 15). Variation of syndicate size over the years is statistically significant at 5\% level. As Panel A shows, the hot IPO periods of mid 1990s have larger size syndicates on average than the later IPOs.

Panel B compares syndicate sizes of IPOs from developed countries to those from emerging markets. Both the average and the median figures show that emerging market ADRs require more underwriters than developed market ADRs although the difference is not statistically significant. The fact that emerging market IPOs require larger syndicate supports the notion that it is more difficult to gather information in developing countries and hence the need for more underwriters.

Privatization IPOs require an average of 25 (median 25) underwriters while non-privatization IPOs require an average of about 17 (median 14) underwriters and the difference is statistically significant at $5 \%$ level. Privatization issues represent the sale of formerly government owned enterprises and hence the deal is more complex.

The other groupings in Table 2 don't show statistically significant differences. Hi-Tech industry IPOs require fewer underwriters than others, but the difference is not significant. Firms whose CEOs are chairman of the board require more underwriters than others, but the difference is not significant. CEO being chairman of the board implies tight corporate control. Similarly, if insiders own 5\% - 25\% of the shares, it implies greater managerial entrenchment following Morck, Shleifer and Vishny (1988) and hence a need for large syndicate to gather adequate information. But the results here, although consistent with these views, are statistically not significant.

\section{Regression Analysis}

Tables 3 and 4 present heteroskedasticity corrected regression results of syndicate size on various explanatory variables. In Table 3 syndicate size is the dependent variable; in Table 4 log transformed syndicate size is the dependent variable. Also in Table 4, total asset size and the total value of shares issued are log transformed. 
Table 2: Descriptive Statistics Of Syndicate Size

Syndicate Size Comparison By Different Classifications

\begin{tabular}{|c|c|c|c|c|}
\hline A) Year of Issue* & $\mathbf{N}$ & Mean & Median & Std. Deviation \\
\hline 1990 & 1 & 50.00 & 50.00 &. \\
\hline 1991 & 1 & 73.00 & 73.00 & \\
\hline 1992 & 2 & 36.50 & 36.50 & 38.89 \\
\hline 1993 & 15 & 26.40 & 19.00 & 20.59 \\
\hline 1994 & 23 & 20.26 & 19.00 & 14.16 \\
\hline 1995 & 21 & 25.05 & 25.00 & 12.51 \\
\hline 1996 & 36 & 21.86 & 23.00 & 9.78 \\
\hline 1997 & 23 & 15.04 & 14.00 & 9.06 \\
\hline 1998 & 15 & 12.27 & 10.00 & 9.83 \\
\hline 1999 & 19 & 7.42 & 5.00 & 5.47 \\
\hline 2000 & 29 & 8.21 & 6.00 & 6.22 \\
\hline 2001 & 3 & 11.67 & 11.00 & 4.04 \\
\hline Total & 188 & 17.63 & 15.00 & 13.94 \\
\hline \multicolumn{5}{|l|}{ B) Country Development } \\
\hline Emerging market issuer & 55 & 19.93 & 16.00 & 14.93 \\
\hline Developed Market Issuer & 133 & 16.68 & 14.00 & 13.46 \\
\hline Total & 188 & 17.63 & 15.00 & 13.94 \\
\hline \multicolumn{5}{|l|}{ C) Privatization* } \\
\hline Non-Privatization & 167 & 16.72 & 14.00 & 13.10 \\
\hline Privatization & 21 & 24.86 & 25.00 & 18.18 \\
\hline Total & 188 & 17.63 & 15.00 & 13.94 \\
\hline \multicolumn{5}{|l|}{ D) Industry } \\
\hline Non-Hi-Tech Issuer & 105 & 18.78 & 16.00 & 13.76 \\
\hline Hi-Tech Issuer & 83 & 16.18 & 14.00 & 14.11 \\
\hline Total & 188 & 17.63 & 15.00 & 13.94 \\
\hline \multicolumn{5}{|l|}{ E) CEO } \\
\hline CEO is not Chairman of board & 126 & 16.49 & 13.50 & 12.88 \\
\hline CEO is chairman of board & 62 & 19.95 & 17.00 & 15.74 \\
\hline Total & 188 & 17.63 & 15.00 & 13.94 \\
\hline \multicolumn{5}{|l|}{ F) Insider Ownership } \\
\hline Insider ownership outside 5\%-25\% & 152 & 18.34 & 15.50 & 14.56 \\
\hline Insider Ownership between $5 \%$ and $25 \%$ & 36 & 14.67 & 12.50 & 10.63 \\
\hline Total & 188 & 17.63 & 15.00 & 13.94 \\
\hline
\end{tabular}

* mean difference between categories significant at 5\% level

Ownership concentration, measured by $\mathrm{HH}$ index, and lead underwriter rank are the only variables with significant positive coefficients when syndicate size is the dependent variable. Positive relation between $\mathrm{HH}$ index and syndicate size is consistent with what is hypothesized. High concentration of ownership requires greater effort to generate information and hence large size syndicate. The positive coefficient with underwriter rank is inconsistent with expectation. If the lead underwriter is highly reputed, it is likely that it has large capital at its disposal and the need to invite large syndicate diminishes. Privatization dummy is marginally significant at $10 \%$ level in the third model. Its coefficients are consistently positive in each of the models. Given that privatization issues involve transfer of ownership and control from government to the private sector, it is more complicated and requires relatively larger syndicate size. 
Table 3. Heteroskedasticity Adjusted Multiple Regression Results

Dependent Variable Is Syndicate Size. Independent Variables Are As Defined In Table 1.

\begin{tabular}{|c|c|c|c|}
\hline Variable Name & \multicolumn{3}{|c|}{ Estimated Coefficients } \\
\hline NEW & $-12.52700 * * *$ & $-12.51400 * * *$ & $-12.95700 * * *$ \\
\hline DEV & 1.20540 & 1.08410 & 2.26620 \\
\hline HITECH & 0.35377 & 0.37297 & 0.29769 \\
\hline TRANSP & -0.82818 & -0.81197 & -0.92312 \\
\hline НHB & $8.13590 * *$ & $8.06360 * *$ & $7.98380 * *$ \\
\hline DILUTION & $-0.02706 * * *$ & $-0.02669 * * *$ & $-0.02786 * * *$ \\
\hline PARTICI & -0.02462 & -0.02334 & -0.02160 \\
\hline OFFERV & $-0.00003 * * *$ & $-0.00003 * * *$ & \\
\hline $\mathrm{TA}$ & -0.00002 & & -0.00006 \\
\hline REVG1 & $-0.00241 * * *$ & $-0.00239 * * *$ & $-0.00240 * * *$ \\
\hline PROCEEDS & $-6.87950 * *$ & $-6.84070^{* *}$ & $-6.44490 *$ \\
\hline IR & 0.00324 & 0.00325 & 0.00442 \\
\hline AGE & -0.03506 & -0.03505 & -0.03304 \\
\hline SNPRE1 & 0.06014 & 0.06064 & 0.07669 \\
\hline URANK & $1.68630 * *$ & $1.69150 * *$ & $1.68010 * *$ \\
\hline PPADJU & -0.01423 & -0.01470 & -0.01386 \\
\hline PVADJU & 0.00494 & 0.00393 & 0.00947 \\
\hline REGIWAIT & $-0.01051 * *$ & $-0.01053 * *$ & $-0.01004 *$ \\
\hline RISK & -0.52642 & -0.52149 & -0.52755 \\
\hline SNPQ & 0.01918 & 0.01803 & 0.02898 \\
\hline INSIDER & -0.01070 & -0.01039 & -0.00831 \\
\hline PRVT & 5.96440 & 5.64070 & $6.90060 *$ \\
\hline CONSTANT & $13.02800^{*}$ & $13.00000 *$ & $11.95500^{*}$ \\
\hline $\mathrm{N}$ & 174 & 174 & 174 \\
\hline R-Squared & $42.29 \%$ & $42.28 \%$ & $41.66 \%$ \\
\hline
\end{tabular}

$* * *, * *$ and $*$ indicate significance at $1 \%, 5 \%$ and $10 \%$ level respectively

NEW, the dummy variable with a value of 1 for issues after 1996 and 0 otherwise, has a significant negative coefficient. This is consistent with the trend. Underwriting syndicate size is decreasing over time for various reasons as stated by Wirth (1997) and Tunick (2004). Dilution has significant negative coefficient. This indicates that issuing more new shares decreases ownership concentration and makes it easier for underwriters to generate information. Offer size (in dollars) has significant negative coefficient. This is inconsistent with expectations since large size offering requires large underwriting capital and hence large syndicate. Revenue growth rate of issuer also has significant negative coefficient. Companies with high growth rate are probably less complicated to require large syndicate especially if they are young. The negative coefficients for the Age variable are consistent with this notion, but they are statistically insignificant. The PROCEEDS dummy which indicates whether the issuer receives some proceeds from the IPO issue or not, has significant negative coefficient. If the issuer receives proceeds from the issue, there may be strong interest on the part of the company executives to limit the syndicate size in order to reduce total issuing cost. REGIWAIT, waiting time in registration with the SEC, has significant negative coefficient, which indicates issues with small size syndicate may not satisfy SEC disclosure requirements that easily. SEC requests revision and modification if the original filing is not satisfactory. This result supports the information generation role of underwriters.

The results based on log transform of syndicate size, issue size in dollars and total assets are similar. As Table 4 shows the only changes are that HH index, PROCEEDS, and log of issue size are not significant anymore. Developed country dummy and transparency environment become significant. The results imply that developed country issues require larger size syndicates than emerging market issues. This is inconsistent with the results in Table 2 and with the notion that emerging markets environment is more complicated and less transparent. The negative coefficient for the transparency variable is consistent with expectations. Issues from more transparent environments require small syndicates. 
The overall results indicate that the time trend, ownership concentration, the transparency of the issuing environments and growth rate of the issuer dominate other factors in determining syndicate size. The size of the company, issue size, risk and stock market performance around issue time are not significantly important. Also no significant relation is found between syndicate size and IPO underpricing.

Table 4. Heteroskedasticity Adjusted Multiple Regression Results

Dependent Variable Is Log Of Syndicate Size. Independent Variables Are As Defined In Table 1.

\begin{tabular}{|c|c|c|c|}
\hline Variable Name & \multicolumn{3}{|c|}{ Estimated Coefficients } \\
\hline NEW & $-0.73628 * * *$ & $-0.70987 * * *$ & $-0.73996 * * *$ \\
\hline $\mathrm{DEV}$ & $0.28817 *$ & $0.28424 *$ & $0.31501 *$ \\
\hline HITECH & -0.09017 & -0.09592 & -0.10440 \\
\hline TRANSP & $-0.13031 * *$ & $-0.13029 * *$ & $-0.13117 * * *$ \\
\hline НHB & 0.32715 & 0.40946 & 0.30059 \\
\hline DILUTION & $-0.00136 * * *$ & $-0.00141 * * *$ & $-0.00135 * * *$ \\
\hline PARTICI & 0.00188 & 0.00097 & 0.00208 \\
\hline LVALUE & -0.01629 & -0.00145 & \\
\hline LTA & 0.05052 & & 0.04288 \\
\hline REVG1 & $-0.00011 * * *$ & $-0.00011 * * *$ & $-0.00011 * * *$ \\
\hline PROCEEDS & -0.11528 & -0.16966 & -0.11614 \\
\hline IR & 0.00023 & 0.00013 & 0.00016 \\
\hline AGE & -0.00157 & -0.00116 & -0.00160 \\
\hline SNPRE1 & 0.02384 & 0.02306 & 0.02387 \\
\hline URANK & $0.22291 * * *$ & $0.23660 * * *$ & $0.22141 * * *$ \\
\hline PPADJU & -0.00007 & -0.00008 & -0.00025 \\
\hline PVADJU & 0.00076 & 0.00038 & 0.00086 \\
\hline REGIWAIT & $-0.00065^{*}$ & $-0.00066^{*}$ & $-0.00066^{*}$ \\
\hline RISK & -0.03545 & -0.04753 & -0.03330 \\
\hline SNPQ & 0.00385 & 0.00354 & 0.00397 \\
\hline INSIDER & -0.00224 & -0.00263 & -0.00210 \\
\hline PRVT & 0.20120 & 0.28771 & 0.20112 \\
\hline CONSTANT & 0.78732 & 0.89491 & 0.74395 \\
\hline $\mathrm{N}$ & 174 & 174 & 174 \\
\hline R-Squared & $44.56 \%$ & $44.10 \%$ & $44.48 \%$ \\
\hline
\end{tabular}

$* * *, * *$ and $*$ indicate significance at $1 \%, 5 \%$ and $10 \%$ level respectively

\section{CONCLUSION}

This study examines the factors that influence the underwriting syndicate size in global IPO offering. Previous studies state that underwriters have a major role of information generation. Consistent with that I hypothesized that transparency environment, corporate governance, risk, market conditions, size of issue, size of the issuer, potential future business relationships, complexity of the deal and the need to share skills determine syndicate size. Empirical analysis presented supports at least partly that ownership concentration, dilution, growth stage of the issuer, transparency environment and the time trend significantly influence syndicate size.

There are some issues that this study raises but does not answer. Further study is necessary to establish the extent to which underwriters invite each other to syndicates for potential business relationships. Risk is found to have insignificant effect in this study. This is probably due to the different risk management techniques available to investment banks today. There may also be differences in the riskiness of the IPO company, which is measured in this study, and the risk from the economic environment at the time of the issue. The effect of risk during hot and cold IPO periods may be different. The repeal of the Glass-Steagall Act in 1999 allowed commercial banks, investment banks and investment companies to merge. Such mergers increase the capital available to the underwriter and decrease the need to form syndicate to share capital commitment. Such recent trends should be examined in future studies. 


\section{REFERENCES}

1. Benos, E. and Weisbach, M.S., (2004) Private Benefits and Cross-Listings in the United States. NBER Working Paper \#10224.

2. Carter, R. and Manaster, S. 1990, Initial Public Offerings and Underwriter Reputation. Journal of Finance, 45, 1045-1068.

3. Chen, H.C. and Ritter, J. 2000, The Seven Percent Solution. Journal of Finance 55, 1105 - 1131.

4. Corwin, S.A. and Schultz, P. 2005, The Role of IPO Underwriting Syndicates: Pricing, Information Production, and Underwriter Competition. Journal of Finance 60, 443-486.

5. Dyck, I.J. A. and Zingales, L., (2002) Private Benefits of Control: An International Comparison CEPR Discussion Paper No. 3177.

6. Ejara, D. D. and Ghosh, C. 2004, Underpricing and Aftermarket Performance of American Depositary Receipts (ADR) IPOs. Journal of Banking and Finance 28, 3151-3186.

7. Foster, F.D., 1989, Syndicate Size, Spreads, and Market Power during the Introduction of Shelf Registration. Journal of Finance, 54, 195-204.

8. Kaufmann, Daniel, Aart Kraay, and Massimo Mastruzzi, 2003, Governance Matters III: Governance Indicators for 1996-2002. Available from www.worldbank.org/wbi/governance/govdata2002.

9. Morck, R., Shleifer, A., and Vishny, R., 1988, Management Ownership and Market Valuation: An Empirical Analysis. Journal of Financial Economics 20, 293-315.

10. Ritter, J. R. 2001, Carter-Manaster Reputation Rankings for IPO Underwriters 1980-2000 Available from http://bear.cba.ufl.edu/ritter/Rank.htm.

11. Smith, R.C. and Walter, I. 2003, Global Banking, Second Edition, Oxford University Press, New York.

12. Torstila, S. 2001, The Distribution of Fees Within the IPO Syndicate. Financial Management, Winter, 25-43.

13. Tunick, B. E., 2004, Say Goodbye to the Syndicate. Investment Dealers' Digest, June 28, 28-35.

14. Wirth, Gregg, 1997, Is This the Death of Syndicate? Investment Dealers' Digest, April 21, 20-26. 